\title{
Debaryomyces 属の抗原に関劣る研究
}

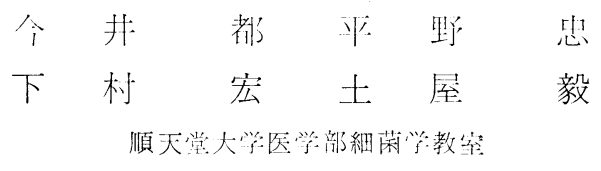

Lodder ら"は1952年状突边を有する子囊胞子と糖類 の弱発酵性を特徵とする醉舟を Debaryomyces 属亡し, Debaryomyces hansenii など 5 種を諗めたが，D. globosus が咄発酥性であるので Saccharomyces rosei の同義語とし

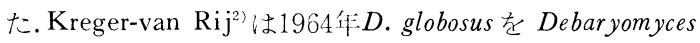
属の type speciesとし，新種を会めて Debaryomycesを 10種とした。最近 Lodder ら² は D globosus の突起が 微小であるとして再び Saccharomyces にもどし，S. kloeckerianus としている。これより先佐野 ${ }^{4)}$ は 5 種の Debaryomyces を，ひきつづき渡辺 原分析を行なつて抗原槛造圭示し，それらの血清学的類 縁閔係を淪じたが，われわれもこのたび 4 種のDebaryomyces の抗原分析を行なつたので，こ机を報㘶する。

\section{实験材料お心び実験方法}

使朋菌株：抗原分析に用いた简種はDebaryomyces castellii CBS 2923 D. cantarellii CBS 4349, D. franciscae CBS 2926, D. tamarii CBS 4333の4菌種であつて, こ のほかに因子血清の作製や凝集反応用抗原などに，従来 の垁駼に脙いたCandida, Torulopsis, Kloeckera, Saccharomyces, Hansenula, Pichia, Schwanniomyces 抢よび他の Debaryomyces 属に属する菌㮔も数多く用いた。

動物の免疫, Slide 凝集反灾，抗体の吸收などのため に使用した抗原の作製力法，および负疫斯物の選択，免 疫反応の術式等は，专べて著者らの 1 人である今井(能

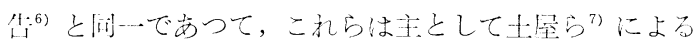

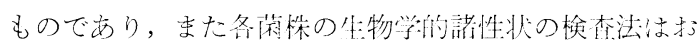

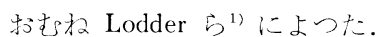

\section{实稀結果.}

\section{I. 耐熱怪抗原}

まず共通抗原をたがいにもたない、Candida albicans， Cryptococcus neoformans, Schizosaccharomyces pombe, Rhodotorula glutinis 拉よ゙ $R$. minuta の哜群の未吸収抗血

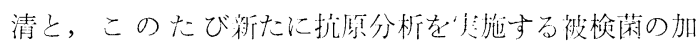
熱菌を，別個に混ぜて Slide 凝焦文心圭行なつたとこ ろ，4種のDebaryomyces 虫 C. albicans の未吸收㷛疫

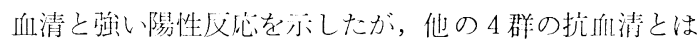
Slide 凝集文応が隍性であつた。それ故これら4種のす べては C. albicans と其通の抗原をもつこととなる。わ れわれはこ礼を耐整性抗原 1 としているので,これらの 諸菌種は抗原 1 をもことになる。

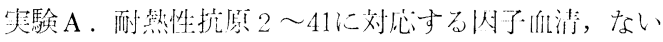
し吸収血清を肌いて，4面の Debaryomyces の熱処理

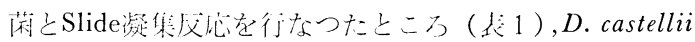

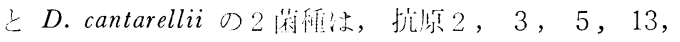

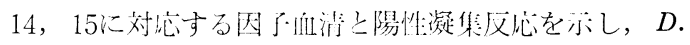
franciscae は抗原 2，3，24，27の因与血清と，またD.

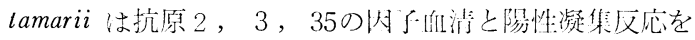
示したが，その他の抗原に刘応寺る内子血淤上は陰性で

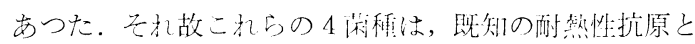

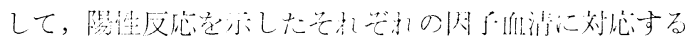

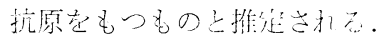

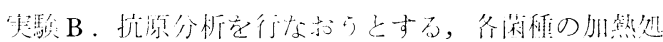

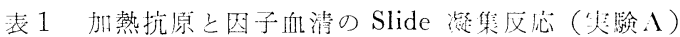

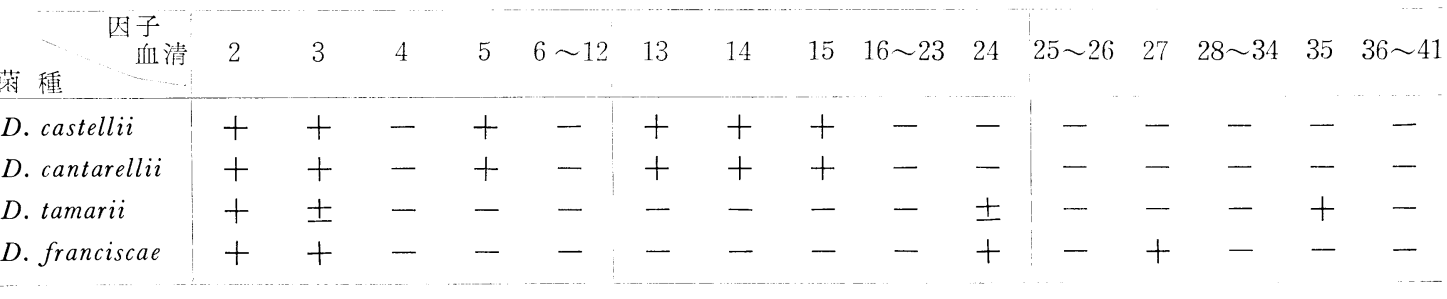


表 2 逐次吸収に上る耐熟性抗原の検索（実験 B )

\begin{tabular}{|c|c|c|c|c|c|c|c|c|c|c|c|c|c|c|c|c|c|c|}
\hline \multirow{2}{*}{$\begin{array}{l}\text { 实 } \\
\text { 験 } \\
\text { 羂 } \\
\text { 号 }\end{array}$} & \multirow{2}{*}{$\begin{array}{l}\text { 抗 加 熱 } \\
\text { 莳 IIIL 消 }\end{array}$} & \multirow{2}{*}{ 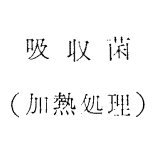 } & \multicolumn{6}{|c|}{ 抗 } & 原 & ( $\mathrm{sm}$ & \multicolumn{2}{|c|}{ 熱 } & \multicolumn{2}{|c|}{ 理） } & \multirow[b]{2}{*}{ 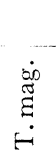 } & \multirow[b]{2}{*}{$\begin{array}{l}\dot{0} \\
\frac{0}{0} \\
\dot{0}\end{array}$} & \multirow[b]{2}{*}{$\begin{array}{c}\dot{0} \\
\dot{0} \\
\dot{n}\end{array}$} & \multirow{2}{*}{$\begin{array}{l}\text { 吸取後残份 } \\
\text { 与る抗体 }\end{array}$} \\
\hline & & & $\begin{array}{l}\dot{y} \\
\tilde{g} \\
\dot{a}\end{array}$ & $\begin{array}{l}\dot{\vec{J}} \\
\dot{U} \\
\dot{a}\end{array}$ & $\begin{array}{l}\dot{\xi} \\
\stackrel{\Xi}{ \pm} \\
\dot{0}\end{array}$ & $\begin{array}{l}\dot{\Xi} \\
\dot{\Xi} \\
\dot{D}\end{array}$ & $\begin{array}{l}\dot{\vec{\sigma}} \\
\dot{0}\end{array}$ & $\begin{array}{l}\dot{a} \\
\dot{0}\end{array}$ & $\begin{array}{l}\dot{\Xi} \\
\dot{u}\end{array}$ & $\begin{array}{l}\dot{\vec{d}} \\
\dot{N}\end{array}$ & $\begin{array}{l}\dot{g} \\
\dot{b} \\
\dot{0}\end{array}$ & $\begin{array}{l}\dot{\Xi} \\
\dot{\Xi}\end{array}$ & $\begin{array}{l}\dot{\vec{d}} \\
\dot{n}\end{array}$ & $\begin{array}{l}\dot{2} \\
\dot{0}\end{array}$ & & & & \\
\hline 1 & D. cast. & C. alb. & + & + & - & - & - & + & + & + & - & + & + & - & - & - & - & $13,14,15$ \\
\hline 2 & As. ( 1 ) & C. zey. & + & + & - & - & - & + & + & - & - & + & \pm & - & - & - & - & 14,15 \\
\hline 3 & As. (2) & D. han. & + & \pm & - & - & - & \pm & + & - & - & - & - & - & - & - & - & 15 \\
\hline 4 & As. (3) & C. pul. & - & - & - & - & - & - & - & - & - & - & - & - & - & - & - & \\
\hline 5 & D. cant. & C. alb. & + & + & - & - & - & + & + & + & - & + & + & - & - & - & - & $13,(14), 15$ \\
\hline 6 & As. (5) & C. zey. & + & + & - & - & - & + & + & - & - & \pm & - & - & - & - & - & (14), 15 \\
\hline 7 & As. (6) & C. pul. & - & - & - & - & - & - & - & - & - & - & - & - & - & - & - & \\
\hline 8 & D. tam. & C. alb. & - & - & + & - & - & - & - & - & - & - & - & - & + & - & - & $35,44 *$ \\
\hline 9 & As. (8) & T. mag. & - & - & + & - & - & - & - & - & - & - & - & - & - & - & - & $44 *$ \\
\hline 10 & As. (9) & D. tam. & - & - & - & - & - & - & - & - & - & - & - & - & - & - & - & \\
\hline 11 & D. fran. & C. alb. & + & + & - & + & - & + & + & - & - & + & - & - & - & + & + & 24,27 \\
\hline 12 & As. (11) & S. ros. & - & - & - & + & - & - & - & - & - & - & - & - & - & + & - & 27 \\
\hline 13 & As. (12) & D. glob. & - & - & - & - & - & - & - & - & - & - & - & - & - & - & - & \\
\hline
\end{tabular}

D. cast.: D. castellii D. cant.: D. cantarellii D. tam.: D. tamarii D. fran.: D. franciscae C. alb.: C. albicans C. pk.: C. parakrusei C. pul.: C. pulcherrima C. zey.: C. zeylanoides C. glm.: C. guilliermondii D. han.: D. hansenii S. cer.: S. cerevisiae C. pt.: C. pseudotropicalis T. mag.: T. magnoliae D. glob.: D. globosus S. ros.: S. rosei As.: 吸收血清（只験番号）＊：新耐熱性抗原

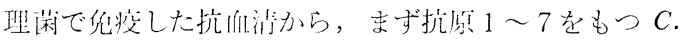

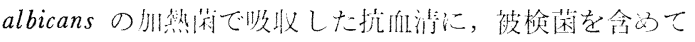

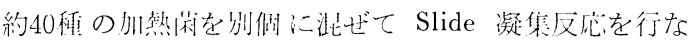

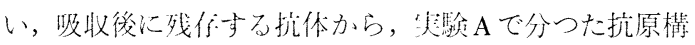
造を確かめた。ひきつづこの收收血清から抗原構造の すでに樹立されている唃相で，なるべく1つずつの抗原 に対応する抗体を順次に吸收した後で，そのたび年に Slide 凝集义仙を行なつて, 残佸抗体から抗原構造を確か めることにつとめた.すなわち牙験 1 ～4 は D. castellii の逐次吸仪试鰻のり駼であつて, まず扰 D. castellii 加 熱菌血清力らC. albicans の掕藏で吸收して Slide 凝

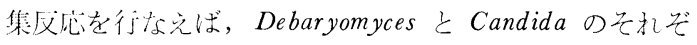

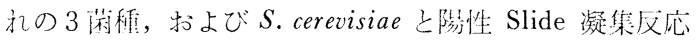
を亦した（圭2）。こ扎は吸收们湖に存在する抗原13，

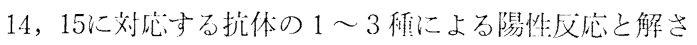
れる。次にこの吸收㚗沙から抗原13孝もつC. zeylanoides の加熱蔽で吸收して，间じょうに Slide 㠜集反応を行な つたところ，抗原14末たは15，ないしその网者を有する 菌種之凝集反応が隄性であつた。そこでひきつづき，京 ず抗原14をもつD. hansenii で，次に扰原13，140ほか に抗原15をもつC. pulcherrima で吸収し，てのたび辂に
Slide 㠜集反応を行なつた。実験 3 では抗体15をもつ潃 種と陽性反応を示したが，残存していた抗体は寒騟 4 で 完全に吸收し尽された。これらの諸実験ならびにひきつ ついて行なつた抗原分析において, 吸収血清と混ぜて凝 集反応を行なつた抗原は表示した菌種だけでなく，抗原 的に関連を有する10種の Candida，2 種の Torulopsis，7 㮔の Hansenula， 2 種の Kloeckera，6種の Saccharomyces および Wickerhamia 属の 1 種など，合計39種の抗原を用 いたが，スペースの関係ですべての菌種に関する反応は 表示しない。しかしこれらの実験から D. castellii は抗 原 $1 ， 2 ， 3 ， 5 ， 13 ， 14 ， 15$ をつ菌種であることに なる。

次に金駼 5〜7に打いて, 抗 D. cantarellii 血清から 逐次吸收を行なつた抗血清との Slide 凝集反心灾の結蝀 も，D. castelliiの場合と汪とんど同じであるが，舁験 6 において, C. albicans 亡 C. zeylanoides の両者で吸收 した抗 D. cantarellii 血清は, 抗原14をもつS. cerevisiae やD. hansenii と反応が陰性ないし痕跡陽性であつた。 これはは抗D. cantarellii 血清中に抗原14の抗体が众如ない し微䊆であるからと解され，言い換えればD. cantarellii の抗原14は抗体産生能が弱いものと考えられる。このよ 
らな抗原は土屋ら゙にしたがつて括弧を附して示した。 したがつて D. hansenii で吸収する必要はないことにな る。次に実験 7 に拈いて, C. pulcherrima の加熱菌で吸 収したところ，抗原15 の抗体も吸収されて，すべての 抗体が吸収し尽された。 したがつて D. castellii と D. cantarellii は抗原的に同一と考兵られる. 同様にして, C. albicans の加熱菌で吸収した抗 D. tamarii 血清は $D$. tamarii と T. magnoliae にの又凝集し, 抗原35の存在が 推定されたので, この吸収血清から抗原35をもつ $T$. magnoliae の加熱菌で再び吸収すると, homologous の菌 とのみ陽性凝集反応を示した。 そこで D. tamarii の加 熱菌で吸収すると，すべての抗体がはじめて吸収し尽さ れた。 それ故 D. tamarii 性独自の耐熱性抗原を有する ことになりわわわれはこの抗原を新たに抗原 44 と名 づけた. したがつて D. tamarii の耐熱性抗原の抗原構 造は抗原 $1 ， 2 ， 3 ， 35,44$ ということになる. 最後に D. franciscae については, その抗血清からC. albicans
S. rosei, D. globosus などで逐次吸収を行なつた上, Slide 凝集反応を実施した場合の結果は，これまでの他の実験 結果と同じように, D. franciscae の抗原構造は抗原 1 , 3，24，27で D. globosus のそ机と近似であつた。

実験C．D. castellii など 4 菌種の抗原㮖造は実験 B よつても確かめられたが，さらに抗原的に同一ないし近 似の菌種と組合せて，相互吸収を行なつた抗血清につい ても Slide 凝集反応を行ない, この而からも抗原構造を 確かめた(表 3). 寸なわち契験14一Aに打いて，抗 $D$. castellii 血清から D. cantarellii の加熱菌で吸収した抗 血清は, すべての菌と凝集反応が㓌性となり, 吸收後残 存する抗体を証明できなかつた。同様に実験14一Bに拉 いて，逆に抗 D. cantarellii 血清から D. castellii で吸 収した場合の反応も同じであつたから，耐熱性抗原に関 する限りこの実験からもD. castelliiとD. cantarellii と は抗原的に同一であることが示された。ささらに兩菌種は C. pulcherrima や C. zeylanoides 乙も抗原的に近似し,

表 3 相互吸収試験拈上び抗 C. albicans 血清からの吸収による耐熱性抗原の検封（実験 C)

\begin{tabular}{|c|c|c|c|c|c|c|c|c|c|c|c|c|c|c|c|c|c|c|}
\hline \multirow[b]{2}{*}{ 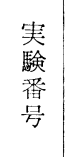 } & \multirow[b]{2}{*}{$\begin{array}{l}\text { 抗 加 熱 } \\
\text { 菌 血 清 }\end{array}$} & \multirow[b]{2}{*}{$\begin{array}{l}\text { 吸 収 菌 } \\
\text { (加熱処理) }\end{array}$} & \multicolumn{7}{|c|}{ 抗 } & \multicolumn{8}{|c|}{ （加 熱 処 理） } & \multirow[b]{2}{*}{$\begin{array}{l}\text { 吸収後残 存 } \\
\text { する 抗 体 }\end{array}$} \\
\hline & & & $\begin{array}{l}\dot{\dot{v}} \\
\text { ठ̃ } \\
\dot{\theta}\end{array}$ & $\begin{array}{l}\dot{\tilde{J}} \\
\dot{\tilde{D}} \\
\dot{0}\end{array}$ & 0 & ฐ్ & $\begin{array}{l}\vec{\sigma} \\
\dot{0}\end{array}$ & $\begin{array}{l}\dot{\vec{d}} \\
\dot{0}\end{array}$ & $\begin{array}{l}\bar{a} \\
\dot{0}\end{array}$ & $\begin{array}{l}\vec{d} \\
\dot{N} \\
0\end{array}$ & $\begin{array}{l}\frac{g}{b 0} \\
0\end{array}$ & $\begin{array}{l}\text { हี } \\
\dot{\Phi} \\
\dot{0}\end{array}$ & $\begin{array}{l}\dot{\Phi} \\
\dot{U} \\
\dot{s}\end{array}$ & $\begin{array}{l}\dot{2} \\
\dot{0}\end{array}$ & 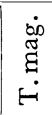 & $\begin{array}{l}\dot{0} \\
\dot{0} 0 \\
\dot{0}\end{array}$ & $\begin{array}{c}\dot{0} \\
\dot{\phi}\end{array}$ & \\
\hline$\overline{14-A}$ & D. cast. & D. cant. & \pm & - & - & - & - & - & - & - & - & $=$ & - & $=$ & $1-$ & - & - & \\
\hline$-B$ & D. cant. & D. cast. & - & - & - & - & - & - & - & - & - & - & - & - & - & - & - & \\
\hline $15-\mathrm{A}$ & D. cast. & C. pul. & + & - & - & - & + & - & - & - & - & - & - & - & - & - & - & \\
\hline$-B$ & C. pul. & D. cast. & - & - & - & 一 & - & - & + & - & - & \pm & - & - & - & - & - & \\
\hline $16-\mathrm{A}$ & D. cant. & C. pul. & - & \pm & - & - & - & - & - & - & - & \pm & - & - & - & - & - & \\
\hline$-B$ & C. pul. & D. cant. & - & - & - & - & - & - & \pm & - & - & - & - & - & - & - & - & \\
\hline$\overline{17-A}$ & D. cant. & D. han. & + & + & - & - & - & + & + & + & - & - & - & - & - & - & - & $(5), 13$, \\
\hline$-B$ & D. han. & D. $\mathrm{C}$ & - & - & 一 & 一 & + & - & - & - & + & + & - & - & - & - & \pm & \\
\hline $18-\mathrm{A}$ & D. cast. & C. zey. & + & \pm & - & - & - & + & + & - & - & + & - & - & - & - & - & (14), 15 \\
\hline$-B$ & C. zey. & D. cast. & - & - & - & - & + & \pm & - & + & \pm & + & - & - & - & - & + & \\
\hline 19-A & D. cant. & C. zey. & + & + & - & - & + & + & + & - & - & + & - & - & - & - & - & (14), 15 \\
\hline$-B$ & C. zey. & D. $c$ & - & - & - & - & + & - & - & + & + & + & - & - & - & - & - & 4, \\
\hline $20-A$ & D. tam. & T. mag. & - & - & + & - & - & - & - & - & - & - & - & - & - & - & - & 44 \\
\hline$-B$ & T. mag. & D. tam. & - & - & - & - & - & + & + & - & - & \pm & - & + & + & + & - & 10 \\
\hline 21-A & D. fran. & D. glob. & - & - & - & + & + & - & - & - & - & - & - & - & - & - & - & \\
\hline$-B$ & D. glob. & D. fran. & - & \pm & 一 & - & - & - & - & - & - & - & + & + & \pm & + & - & 10 \\
\hline $22-\mathrm{A}$ & D. fran. & S. ros. & - & - & - & + & - & - & - & - & - & - & - & - & - & + & - & 27 \\
\hline$-B$ & S. ros. & D. fran. & - & - & \pm & - & + & - & - & + & + & + & - & - & - & - & + & 4 \\
\hline 23 & C. alb. & D. cast. & - & - & - & \pm & + & - & - & + & + & + & - & - & + & + & + & 4 , \\
\hline 24 & C. alb. & . cant. & \pm & - & - & + & + & - & - & + & + & + & - & - & + & + & + & 4, \\
\hline 25 & C. alb. & D. tam. & + & + & - & + & + & + & + & + & + & + & + & - & + & + & + & $3,4,5,6,7$ \\
\hline 26 & C. alb. & D. fran. & + & + & + & - & + & + & + & + & + & + & + & - & \pm & - & + & $2,4,5,6,7$ \\
\hline
\end{tabular}


また D. tamarii は T. magnoliae と, D. franciscae は D. globosus や $S$. rosei とよく類似していることも分つ た。これらの実験のらちまれに新抗原の設定を必要と し，または矛盾する反応もないでもなかつたが抗原構造 の骨格のゆるぎない限り, 安易に抗原の新設をしなかつ た。

次にはじわ可駗 A で用いた吸収血清は単因子血清でな いものもあるので, D. castellii などの 4 被検菌の抗原 $2 \sim 7$ の存否を他の俑から女検討するために, 抗 $C$. albicans 血清から被検菻で吸収して Slide 凝集反応を行 ない, 残存する抗体反応から抗原㮖造の適否を検討し た。すなわちり験23，24に打いて，抗 C. albicans 血清 からそれぞれ D. castellii，D. cantarellii で吸収した抗 血清は抗原 4, 6, 7 をもつ菌種之陽性反応を示し, $D$. castellii などの 2 藏種は抗原 $2 ， 3 ， 5$ に対応する抗体 をそれぞれの抗原で吸収したことを示した（表 3 ）。それ 故両者がこれらの抗原を有するといら実験 $\mathrm{A}$ の結果と矛 盾しないことになる。しかし実験25において D. tamarii で吸収した抗 $C$. albicans 任清は抗原 3，4，5，6， 7 に対応する抗体を残し，D. tamarii が抗原 3 の抗体を 吸収できず，䨋い換えれば或験 A と異なつて D. tamarii に抗原 2 はあるが抗原 3 は存在しなかつたこととなり，

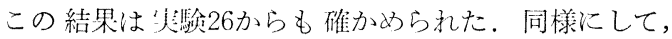
D. franciscae は抗原 3 を斿が，抗原 2 は有していない のである.

\section{II. 易熱性抗原}

耐熱性抗原の抗原分析の場合と同じように，まず易熱 性抗原 $\mathrm{a} \sim \mathrm{n}$ に対応する因子血清を用いて Slide 凝集反 応を行なつた。 D. castellii と D. tamarii は易熱性抗原 a の因子血清と, また D. franciscae は抗原 i の因子血
清と陽性反応を示したが，D. cantarelliiとは陰性であつ た。

次に被検菌の $0.5 \%$ ホルマリン食塩水浮遊液でとれぞ れ動物を免疫して得た抗血清から, 同じ菌種の加熱菌で 吸収し，各菌種の生菌を抗原とする Slide 凝集反応を行 なつた。この実験でも易熱性抗原の因子血清を用いた場 合と同じように D. castellii と D. tamarii に易熱性抗 原aが，また D. franciscae に抗原 i の存在することが 確かめられた。しかし D. cantarellii からはいかなる。易 熱性抗原も証明されなかつた。

\section{III. 生物学的性状}

形態学的特彺ならびに生物学的性状の検査は主として Lodder ら ${ }^{1)}$ にしたがつて行ない，D. franciscae の子囊 胞子は円形であり，はつきりと疫状突起は認められな かつた。しかし他の 3 種の Debaryomyces は疮状突起を 有する 1 〜 個の円形の子囊胞子を形成した。 また発酵 ならびに同化作用の検查結果は表 4 の通りであるが, Kreger-van Rij ${ }^{2}$ のそれと僅少の差は認められるけれど も，活とんど同一といつてよい。ただし D. tamarii の $\mathrm{KNO}_{3}$ の同化作用は陽性であつた。

\section{考察}

Klöcker は疮状突起を壁面にもち，球形の子囊胞子を 形成する酵母を Debaryomyces 属とし ${ }^{1)} ， D$. globosus を

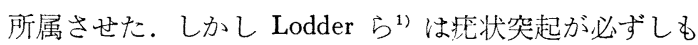
認めやすい性状ではなく，他方 Debaryomyces の中には 強発酵性の菌種と, 弱ないし無発酵性の菌種の混在す ることに気づき，D. globosus を Saccharomyces 属に移し た。ささに Phaff が Pichia 属は菌膜形成を必要としな いとしたので, Kreger-van Rije) は D. vini と D. fluxorum をPichia に移した。，その後 D. globosus の疫状突起は

表 4 生物学的ならびに血清学的性状

\begin{tabular}{|c|c|c|c|c|c|c|c|c|c|c|c|c|c|c|c|c|c|c|c|c|}
\hline \multirow[b]{2}{*}{ 菌 } & \multirow[b]{2}{*}{$\begin{array}{l}\text { 菌 } \\
\text { 種 } \\
\text { 数 }\end{array}$} & 子 & \multicolumn{5}{|c|}{ 醴酵作用 } & \multicolumn{12}{|c|}{ 同 化 作 用 } & \multirow[b]{2}{*}{ 抗 原 } \\
\hline & & $\begin{array}{l}\text { 簬 } \\
\text { 胞 } \\
\text { 子 }\end{array}$ & $\begin{array}{c}\text { プ } \\
\text { ド } \\
\text { ウ } \\
\text { 糖 }\end{array}$ & $\begin{array}{c}\text { ガ } \\
5 \\
\eta \\
r \\
1 \\
セ ゙\end{array}$ & & $\begin{array}{c}\checkmark \\
ル \\
r \\
1 \\
セ ゙\end{array}$ & 乳 & $\begin{array}{c}フ ゙ \\
\text { ド } \\
\text { ウ } \\
\text { 糖 }\end{array}$ & $\begin{array}{c}\text { ガ } \\
\bar{y} \\
\eta \\
r \\
1 \\
\text { ゼ}\end{array}$ & 蔍 & $\begin{array}{c}\nabla \\
\mu \\
r \\
1 \\
セ ゙\end{array}$ & 乳 & $\begin{array}{c}セ \\
\square \\
\text { ビ } \\
\text { オ } \\
1 \\
\text { ゼ }\end{array}$ & $\begin{array}{c}r \\
v \\
\text { N } \\
\square \\
1 \\
\text { t゙ }\end{array}$ & $\begin{array}{c}\text { ラ } \\
7 \\
1 \\
\gamma \\
1 \\
\text { ゼ }\end{array}$ & $\begin{array}{l}\text { キ } \\
\text { シ } \\
\square \\
1 \\
\text { ゼ }\end{array}$ & $\begin{array}{l}\text { サ } \\
\text { リ } \\
\text { チ } \\
\text { ン }\end{array}$ & $\left\{\begin{array}{l}ア \\
\text { ド } \\
= \\
\text { ト }\end{array}\right.$ & $0^{\infty}$ & \\
\hline D. castellii & 1 & RW & + & + & + & + & - & + & + & + & + & - & + & + & + & + & + & \pm & - & $1,2,3(5), 13,14,15$, a \\
\hline D. cantarellii & 1 & RW & + & + & + & + & - & + & + & + & + & + & + & + & + & + & + & + & - & $1,2,3(5), 13,(14), 15$ \\
\hline D. tamarii & 1 & RW & + & + & - & - & - & + & + & - & \pm & - & + & + & + & - & + & - & + & 35,44 , \\
\hline D. franciscae & 1 & $\mathrm{R}$ & + & + & + & + & - & + & \pm & + & - & - & - & + & + & - & - & - & - & $3,24,27$, \\
\hline
\end{tabular}


目視すべきであるとの䫓も少なくなかつたので, Kregervan $\mathrm{Rij}^{2)}$ は S. rosei の同義語とされていた D. globosus を Debaryomyces にもどして，その type species とし た.しかし Lodder ら゙3) は1970年再びこの D. globosus を D. franciscae とともに Saccharomyces 属に移して, それぞれ S. kloeckerianus および S. pretoriensis とし， Debaryomyces 属を 8 菌種とした。

Debaryomyces 属の菌種の 血清学的研究については, 1960你佳野 ${ }^{4)}$ は D. hansenii, D. hansenii var. membranaefaciens, D. kloeckeri および D. nicotianae が血清学的に 间一で，そ㧈らの抗原橧造は耐熱性抗原 1，2，3，4， 9，14であるとし，次いで1961年渡辺 ${ }^{5)}$ は D. marama， D. vini がその牛物学的差にも拘らずD. hansenii 群と同 じ抗原構造であるが，D. subglobosus は D. hansenii の 抗原のほかに抗原33を有し，D. fuxorum は耐熱性抗原 2，5，11と易熱性抗原奋をち，その性状は Debaryomyces よりむしろ Pichia に近似であるとした，さらに

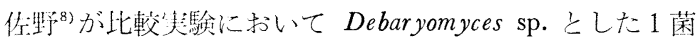
株が，抗原的に D. fluxorum 之一致することを後でわれ 才扎が同定した。な技今井ら は1967年，Saccharomyces の满莉種とともに D. coudertii の抗原分析を行なつて, この体種も弃た D. hansenii と同じ抗原構造をもつと報 行した。かくて血清学的研究を行なつたこれらの研究者 は，たと光物学的性状に美琵があったとしても，そ れらの蔺種が抗原的に同一ならば，最初の種名をもつ種 以外の菌種は独立種とすべきではなく，また逆に同一な いし近似の尘物学的性状を示しても，抗原模造を異にす るならば，別個の菌種とすべさことを強調した。

このたび抗原分析を行なつた D. castellii と D. cantarellii は1961年 Capriotti によつて，それぞれスェー デンとフィンランドの土堙から分離され，ともに疫状壁 をもつ子囊胞子を形成して, ブドウ糖, 蔴糖, マルトー ゼを発徆し，またこ机らとガラクトーゼを同化するとし た。雨者の差は D. castellii の細胞が D. cantarellii の それよりも短く，前者がガラクトーゼを発酵せず，アラ ビノーゼを同化するが，乳糖を同化しない点で後者と異 なるとした。しかしガラクトーゼの発䤉および乳糖の同 化作用に関するわれわれの成䋶は表示の通りであつて, 抗原的にはともに耐熱性抗原 $1 ， 2 ， 3 ， 5 ， 13 ， 14$, 15をもち，D. castellii はこのほか易熱性抗原 aを有与る 菌種であつた。 したがつてこれらは抗原的に C. pulcherrima,$C$. parapsilosis と近似の菌種であつて, 異なる点は 易熱性抗原 $\mathrm{c}$ またはdをもたないことである。
D. tamarii は1954年大原らによつてタマリ（tamarisoya）から分離され，扰状壁を存する了露胞了を形成す る. Kreger-van Rij は本藏がブドウ糖，ガラクトーゼ， 蔗糖および乳糖を発䤀して，またこ机を间化するが， 硝酸カリを利用しないとしたが，われわれの行なつた検 查は表示の通りで, 重裂な相僬点は例酸カリの利月能で あつた。抗原分析によ机ば，D. tamarii は耐熱性抗原 $1 ， 2 ， 35$ 㧍よび独门の抗原 44 之, 易熱性抗原aをも ち，抗原的には D. hansenii, D. coudertii, D. castellii な どとは近似でなく，T. magnoliaeやT. versatilisなどと 近縁な抗原樌造をもつている。

D. franciscael は Capriotti によつて 1958作スペイン の土壤から分離されて, Torulaspora franciscae 亡命名 されたが，1964年罗玉らが Citrus sp. の樹液から分離

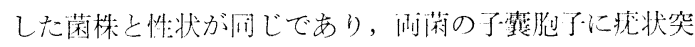
起が浔めら机たので，罗玉五らは Kreger-van $\mathrm{Rij}^{2)}$ とと もに D. franciscae の㑜名を恐めた。しかしすでに1956 年 van der Walt らによつてプレトリアの1:壤から分 離された S. pretoriensis が D. franciscae と類似してい るとして，このたび彼は D. franciscaeを $S$. pretoriensis ${ }^{3)}$

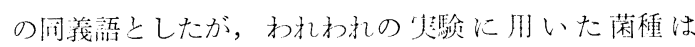
Capriotti の D. franciscae 株それ川体であつて， $S$. pretoriensis 株ではなかつた。年扎故 S. pretoriensis に

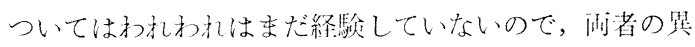
间を确じる段階にはないが，わ扎われの用いた D. fran-

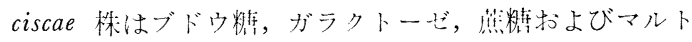
一ゼを発徆素して，また同化したが，硄変カりを利用しな かつた。すなわち D. franciscae と D. globosus の生物 学的性状の装は，ガラクトーゼの発邽ならびに间化作用 拉よびイスリンの间化作朋にある。抗原分析によれば, D. franciscae の耐熱性抗原は 1，3，24，27抢よび易熱 性抗原 $\mathrm{i}$ をち，D. globosus とは抗原10を久く点だ で異なる菌種なのである。

Lodder $5^{1)}$, Kreger-van Rij ${ }^{2}$, Lodder $5^{3)}$, その他に よれば，尊て Debaryomyces に娜痋したことのある菌種

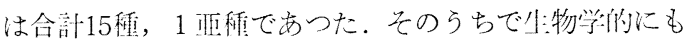
抗原的にも, Pichia と江䋑な D. fluxorum と D. vini は

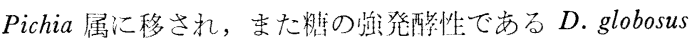

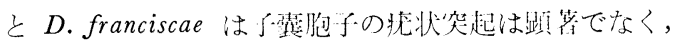
かえつて電子顕微鏡像で $S$. rosei や S. fermentati の子 䨟胞子に疮状突起が涩められたので Torulaspora 群にま とめ, これを Saccharomyces 屈に移した. D. globosus と D. franciscae怯抗原的に汪と九ど间..で，さらにS. rosei 
やS. fermentati とも颣似しているが, van der Walt ら が Torulaspora 群に数壳た Torulaspora delbrueckii ( $S$.

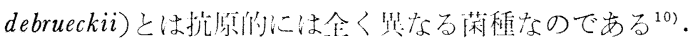
ぬつとも17秼の S. delbrueckii の authentic strain 中で type species 3゙ 4 株の抗原的 $S$. rosei 小にあるならば彼

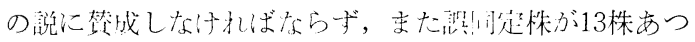

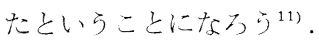

数们の Debaryomyces 蓜 Pichia や Saccharomyces に移 動させた後で，Lodder ら゙は残つたDebaryomyces を2 群に分汁た。すなわち D. coudertii, D. hansenii, D. marama および D. tamarii の 4 盘老体細胞の小さい球形な いし短卵们形，低発降性:の第 1 群としたが，D. tamarii

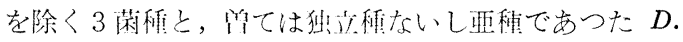
kloeckeri, D. nicotianae, D. hansenii var. membranaefaciens およびすでにPichiaに移さ扎たが，電显的に微抚状 slightly notched wall の了.露胞了索もつ D. vini 等 6 種

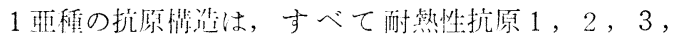
4，9，14であつて易熱性扰原はもつていなかつた。し たがつて D. vini は Debaryomyces とすべきであり，さ らに抗原33を持するD. subglobosus 笹第 1 群にあつても

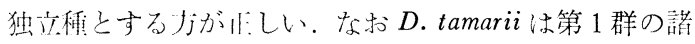

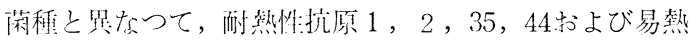

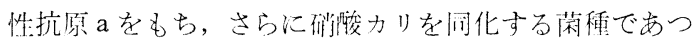
て, むしろ T. magnoliae や T. versatilis 上近似の菻種 であるから，D. hansenii たどの属する第 1 群とは別個 の菌群とすべきである。

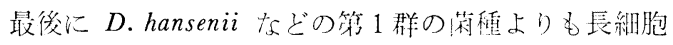

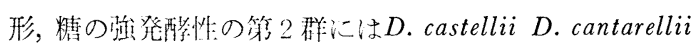
など 4 菻研が所属するとしたが，はじめの 2 菻種は $C$. pulcherrima と抗原的に近縁の莳稩であつた. Lodder ら が本群に所后させた D. vanriji, D. phaffiiの抗原分析は 完了していないが，抗原们には湔者は第 2 群に，後者は 第1群に所屈させるべきものであつた。かて物学的 性状の文に落ついて分類された Debaryomyces は航清学 的研究によつて，より命理们に整师さ机るのである。

\section{結論}

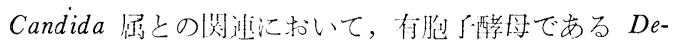
baryomyces 屈の 4 泪柯につき，吸收法を目いる Slide 凝 集反応によつて耐谽性ならびに易效性抗原の抗原分析を

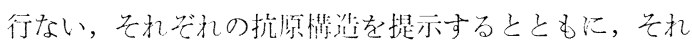

らの生物学的諸性状も検查して, 血清学的類縁関係を考 察した。

D. castellii と D. cantarellii はともに附熱性挬原 1 ， 2，3，5，13，14，15をもち，この活かに前者は易熱 性抗原 a を有して, 血清学的には $C$. parapsilosis や $C$. pulcherrima と近緣である。

D. tamarii は两熱性抗原 1，2，35および独自の抗原 44 之易熱性抗原 a 老もち, 血清学的には T. magnoliae や T. versatilis 亡近縁である。

D. franciscae 洏熱性抗原 1，3，24，27および易熱 性抗原 $\mathrm{i}$ を有し，D. globosus ときわわて近縁であつて， さらに S.rosei S. fermentati と斥類似する菌種である.

\section{文献}

1) Lodder, J. \& Kreger-van Rij, N.J.W.: The Yeasts. A taxonomic study. North-Hclland Publishing Co., Amsterdam, 1952.

2) Kreger-van Rij, N.J.W.: A taxonomic study of the yeast genera Endomycopsis, Pichia and Debaryomyces. Thesis, Leiden, 1964.

3) Lodder, J.: The Yeasts. North-Holland Publishing Co., Amsterdam, 1970.

4) 传野弥文次: Debaryomyces 属の血清学的分類 に関する研究，順天堂医誌，5,50-58，1959.

5) 渡辺善美：酵母の血清学的分類に関する研究補 遺, I, Debaryomyces 属の 4 菌種の抗原分析, 真 菌誌，1，323-329, 1960.

6) 今井都：酵母の血清学的類縁関係に関与る研 究, 第 1 編 Kloeckera と Hanseniaspora の抗原 分析, 真菌誌, 10, 305-315, 1969.

7) Tsuchiya, T., Fukazawa, Y. \& Kawakita, S.: Serological classification of the genus Candida. in Studies on Candidiasis in Japan, 34-46, 1961.

8) 佐野弥文次: Debaryomyces 属の血清学的分類 に関する研究，II，日本細菌誌，14，856-860, 1959 .

9) 土屋 毅, 今并都：数種の隆母の血清学的類 縁関係について, 生理生態, 15, 33-44, 1968.

10) Tsuchiya, T., Fukazawa, Y., Sato, I., Kawakita, S., Yonczawa, M. \& Yamase, Y.: Serological classification of the genus Saccharomyces. Yokohama Med. Bu!l., 9, 359-370, 1958

11) 土屋 毅：䤃母の血清学的分類, バイオテク,2, $171-174,1971$.

（昭和 46 年 5 月 1 日受付） 